3Ga1トロバンアルカロイドの生合成(第 9 報)

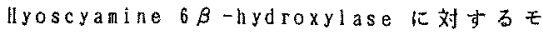
ノクローナル抗体の作製

(京大覀・細胞実倹センター・特殊免疫研) 橋本隆、○天野靖浩、河野淳子、白田定 和・、岩成宏子・、山田康之

1.目的数種の十又科稙物に含有さ机るscopolamine $は$ hyoscyanine(hyos) 加 $56 \beta$-hydroxyhyoscyamine(hyosoH)を経由して合成される。我ヶは既 にhyosthyosollへ水酸化する蟀案hyoscyanine $6 \beta$ hydroxylase(H6H)を発見し、精製することに成功し た。今回、116日k特翼的な千,クロ一ナル抗体を作 製し性質を調へたのので報告する。

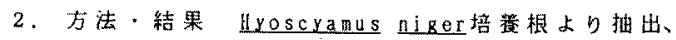
各種クロマトクララフィにより高度に精幣した $\mathrm{H} 6 \mathrm{H}$ タン心゙ク筫をマゥスへ兒废した。計 4 株のそノク口

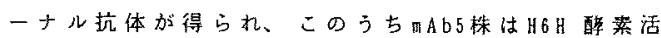
性を阻害した。この株は肘䏦性の存在する数種の

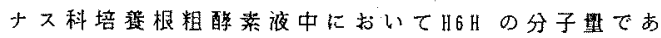
る38kDタンパク貿を認識し、他の3株は上ヨ又属ま

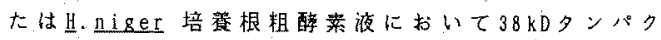
質を認部した。古, niger 植物の花并、がく、葉、莰、

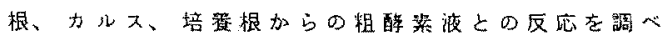
たとしろ、4株全て培意根と植物根のみに反応した。

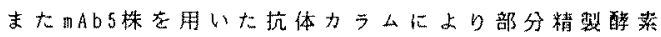

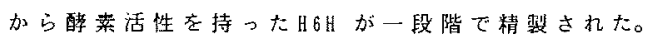

3Ga3トロパンアルカロイトの生合成（第11砕） hyoscyamine $6 \beta$-hydroxylase $\sigma$ C DN A $\eta ロ-=ン ク$

(京大・農・細胞実験センタ一)

○松田閶、岡部宗一、橋本隆、山田康之

1. 目的 Hyoscyanine $6 \beta$-hydroxylase(H6H:EC1. 14.11.11) 岋2ーオキソグルタル酸依存型ジオシゲナ 一ゼであり、いくつかのトロパンアルカロイドの酸 化反纯を触媒する。今回 $116 \mathrm{H} の$ 一次模造及び発現調 節機满の解析を目的にCDNAクローニングを行った。 2. 万法之結果培萣 7 日目の Hyoscyamus niger 培養根上り aRNA を調製し、これを鋳型として CDNA ライブラリーを作製した。胉は端がブロック されているため、ブロテアーゼで分解した数種のべ プチドフラグメントより内部てミ，酸配列を決定し 推定される核酸配列に従いオりゴヌクレオチドプロ ーブを合成し、上钎 CDNA ライブリー加ら口ニ 一八イプリダイゼーション法により晹性クローンを 得た。そのDNA 配列を決定したところ、推定される アミ，酸配列结すへてのベブチドフラグメントの配 列と一致した。また、 $\beta$ ガラクトシダーゼとの瀜合 蟫白を産生させそノクロ一ナル抗体を用いてっェス タンブロッデングを行ったところ、晹性のバンド が見られた。本CDNAを用いたノーザン八イフリダイ ゼーション法により、H6H nRNA は七ヨ又植物の培琵 根及び根で特翼的に発現していることが判明した。

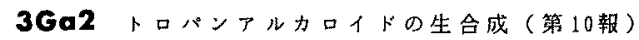
免度組織化学的手法を用いたアルカロイト 生合成細胞の同定

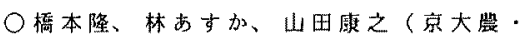
細胞実雅七ンタ一)

1. 目的トロパンフル力ロイトは数㻎のナス科植 物に执いて主に根で合成され、加なりの部分加地上 部へ転流される。しかし、根のどの糿跑でてルカ口 イドが合成されるのか不明である。今回、我々は

hyoscyamine 6 $\beta$-hydroxylase (ll6 H) K特買的なそ， ク口一ナル抗体用いた免疫組絴化学的手法により、 根に护けるテル力口イト生合成盘胞を同定した。

2. 方法・結果 $4 \%$ \%ラホルムアルデヒドにより

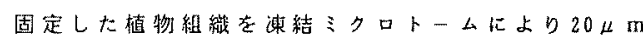
の切片に切つた。ブロッキング後、1次抗体として Hyoscyamus niger H6Hに対して作製したmAb5株を反 応させた。この梅は他の植物の 116 屹を認識する。

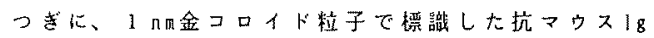
$(H+L)$ †゙抗体と反応させ、銀增感法によりシグナル

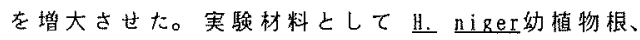
Duboisia leichhardtii培盖根、正 gyorffi培算根等 を用い、コントロールとして1次抗体に通常のマウ 又180店用いた区と、胴Uが存在しない夕バコ根等 を畹5により同様に処理した区を行った。根の維管 束部の内侧の細胞( pericycle と篩部) 付近に強い シグナルが観察された。

$3 G a 4$ Panicum miliaceum (NADーリンゴ酸醭型 C 4 植物) 葉アラニンアミノトランスフェラ

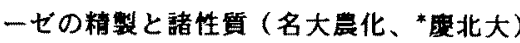
O㮇 大承、*Jo Jinki、杉山達夫

1.目的 アラニンアミノトランスフェラーゼ(AlaAT) はNAD-ME型C 4 植物において炭酸固定経路の胃格醉

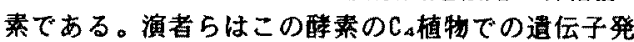

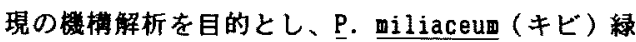
莱から AlaAT を精䌘し、その諸性留を明らかにす るとともに、特異抗体の調製を行った。

2. 方法と結果 緑菜抽出液にはイオン交換クロマ トグラフィーで分離される $2 つ 0$ AlaAT アイソザ イムが存在した。このうち活性の压倒的に多い成分 を硫安分画、ゲル滤遇、イオン交換および眯水性力 ラムクロマトグラフィーにより精製し、電気泳動的 に均一なAlaAT 樌品を得た（比活性、387 $\mu \mathrm{mol} / \mathrm{min}$ /mg protein)。本醅素は分子量的10万であり、約5 万の同ーサイズのサブュニットからなる2量体であ ると推定された。この酻秦は基質に対して、既に報 告されている動物由来の酵素や植物由来の部分精製 標品と類似の Kn を示した。SDS 処理したこの精慗 醇素摽品に対し調製した特異抗体を用いて解析した ところ、AlaAT 主成分は、葉肉細胞と維管束鞘細 胞に分布し、植物の緑化過程で的に発現策猜する ことが判明した。他の植物種の AlaAT との比較結 果についても䂲する。 
$36 a 5$

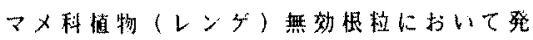
現が的制されている根粒特異的タンパク筫

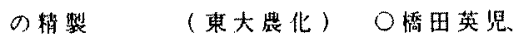
小野寺一清、丸山芳治

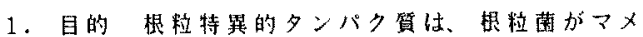
科㨁物に共生することで発現してくるタンパ筫で 夷る。無奻根粒菌によって形成された根植は、根粩 の発達が未熟て、空菜固定老行っていない。をこで ます、有奻根粒と無圽㮛粒の可溶性夕ンパク貎を分 離し、三次元霹第泳動在行い根粒特簧的夕ンバク質

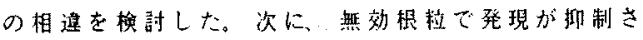

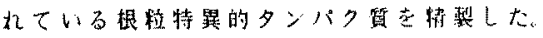

2.方法あらかじ、レンゲ根粒特異的タンバク

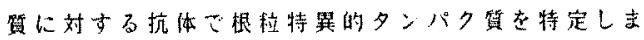

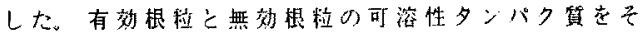

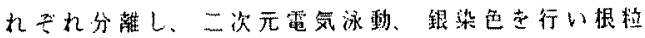

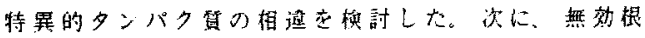

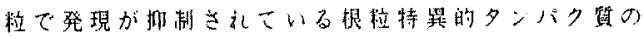
中のーつに注目し、ゲル沪過（HPLC）、クロマ トフォーカシジ、级び进相クロマト(HPLC) を用いて䍹製を行った。

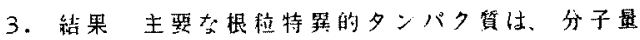
$14 \mathrm{~K} \mathrm{~d}$ に集中しているが、买れらの根粠特異的夕 ンパク質の3つは大美く発現が抑制さ九ていた。 れらのタンパク筫の一つ(等電点 7 ) を精製した。

3 Ga7 ラム夕エキソヌクレアーゼ消化で得たDNA 断片をフライマーとする逆ホリメラーゼ連

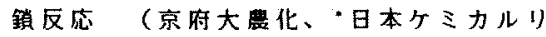
サーチ) 光川典宏、增村威宏・、古賀 淳一・、○大菅裕之、田中國介、莎井昭治 1. 目的睡知ONA配列の外倒の構造を解析する手 法として有用な逆ホリメラーセ連销反応(IPCR)の丁 ライマーとして、ラムタエキソヌクレアーゼ消化で 得たDNA断片を利用できるかどうかを調榃すること、 及びこの手法の一般的利用法の確立を目的としてい る。

2：方法 イネ10kDaフロラミンの全長CDNA配列を pBluescript KStに組み込んたフラスミドpIRP10の CDNA領域からS祭 I/Hinc II 切断で 400 bpの断片在得 た。この断片にラムタェキソヌクレアーゼを作用さ せ一本鎮DNA断片を得、これと元の環状P1RP100共 存下に耐熱性Ta和Aボリメラーゼを用いてPCRを行 دt。

3. 結果 PCR鷹物をアガロース電気放動後EtBr染 色した。その結果鋳型として用いた口IRP10（5ma I 切断で直䍻状としたもの)と同一分子量を示すバン ドが確認出来た。またベクターの配列に対応する 32P一嘅ブローブを用いるササンフロット法でベ クタ一配列の增幅む確認した。以上の結果はラム夕 エキソヌクレアーゼ消化で得られるDNA断片が眔状 北したDNA配列に対するIPCRのブライマーとして 一般的に利用可能なことを示している。

\section{Ga6 花粉に特徽的な蛋白質の検索}

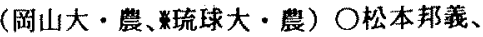 \\ 関谷次郎、下瀨 昇、新城長有
}

目的. 花粉の発生・分化には减数分裂、半数生体細 胞分裂、花粉の発来など多くの重要な過程が含まれ ている。一方花粉は䓎の中で発生・成熟するが、成 熟後は大気にさらされ、耐乾操性などが增加する。 これらの一連の変化峙遗佉情報によって支卧されて いる。ここでは遺伝情報の発荊型である蛋白質に注 目し、花粉の成熟に関与している蛋白質の検索を行 うことを目的とした。

方法と結果、材料にはイネ(Oryza sativa)とテッポ ウユリ(Lilium longiflorun)の花㸭を用いた。花粉 （1５ mg）は少量の等電点電気泳動用緩街液に㮣濁 し、凍結融解を絽り返したのちンニックにより蛋白 頁を抽出した。電気泳動は 0’Farrel1の方法に従つ て等電点とSDS ゲル電気泳動を組合わせた二次元電 気泳動で行い、蛋白は、CBB染色、あるいは銀染色に よって検出した。卫り花粉発生の後期では発生時期 による差はほとんど認められなかった。イネ花粉と イネ培養細胞を比較すると差が諗められた。花韧発 生段階の異なるイネ花羒、および細胞質優性不稔1 ネの花㸮などの蛋白質分析の結果とあわせ花粉蛋白 質の特徵について考察する。

$3 \mathbf{G a 8}$ 花粉 $O \beta-1,3-8$ lucanase

（岡山大・農） ○熊 龍豹、藤井君工、 関谷次郎、下瀨 昇

1. 目的花粉発第は植物の有性生殖の重慗な一過程 であり、発芽の初期過程として細胞壁多糖の部分的 な分解が起こると考えられる。本研究では花粉発芽 の生化学的解明を目的としているが、今回は花粉中 の $\beta-1,3-$ glucan (callose) を加水分解する $\beta-1,3-$ glucanase 活性について検討した。

2. 方法 材料としてテッ将ウコリの花粉、睢すい、 そして葉を用いた。0.1Mリン酸緩衙液 $(\mathrm{pH} 7)$ で抽 出し、硫安沈役之诱析に上って粗睹素を得、 $\beta \cdots 1,3$ glucanase 活性を測定した。また花粉を人工培地上 で発芽させ、経時的に本酵甞活性を测定した。ß一 1，3-glucanase 活性はラミナリンを基質として用い、 生じた邊元末端の增加をSomogi-Nelson 法で定量し て求めた。

3.結果 本酵蒵は花粉、雌ずい（柱頭、花柱、子房） および葉に分布し、その活性は花叛が最も高く、新 鲜重1gあたり、12.3 nKatであった。これは葉の10 倍、柱頭の15倍、花柱および子房の100倍であった。 また、花粉発芽に伴う本酥素活性の变動は諗められ なかった。CH1 は花粉発芽を阻害し、かつ本醉素の 活性を低下させた。本酵素は酸性領域に等電点を有 すると推定されるが、現在精製を試みている。 
3609海性監蒌由来の不定肧発芽促進因子

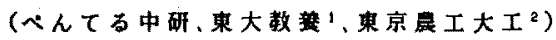

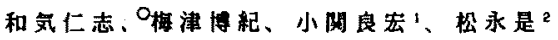

1 . 目的涌者らは、海洋性篮莯抽出物中にニンジ 不定肧の成照促進因子と発芽促進因子が存在するこ とを報告した”。今回は、発芽促進因子の不定胚に 対する作用についてさらに検尉を加え、併せて有勃 成分の特定を就みた。

2.方法海洋性藍 Synechococcus sp.の紫水抽出 物から透析に上り発芽促進因子を含む非透析画分を

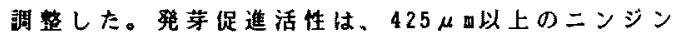
不定肧考明条件下 1/4 KS培地中で6日間培美し再生 した植物体数を計洞し部面した。有奻成分の棈㱔は 各種クロアクラフイを角いて行った。

3.䊅果 Synechacoccus sp.MRBG 042902抽出物の非 透析西分支 $100 \mu \mathrm{g} / \mathrm{ml}$ 添加した時、 $800 \mu$ 㕽上に成

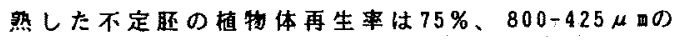

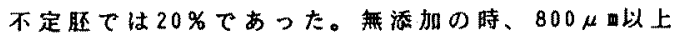

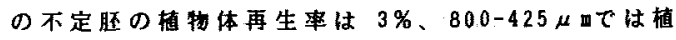
物体の再生は㤎め5なかった。発芽促進因子は、発 芽本を向上させるとともにその進行を促進した。ま

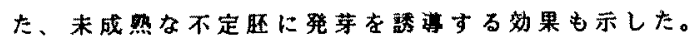
この画分を各直加水分解酸素による分解とゲル油通 分西て有効成分の特定を行った。

1)和気 $5 ; 1989$ 年度层化大会要旨集、P175

3Ga11チモシーがまの穗病病徽部からの新規スフィン

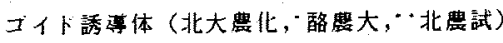
○越野広雪，奥野美智，吉原照应，市原耿民，

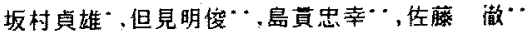

1.目的チモシ一は、がまの德病(Epichloe typhina)に感 染することにより斑点病(Cladosporium phlei)に対して誘 望抵抗性を示す。抵抗性発現機满の解明を目的に、がまの

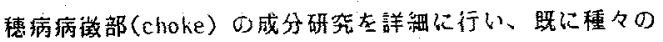
新規抗菌物筫について報告したい。今回は、新たに单離し た新規化合物の構造決定について㪕告する。

2.方法及じ結果 Choke $(20 \mathrm{~kg})$ 抽出物の融酸工开儿可溶部 より各種クロマトクラフィー及びHPLCを用いて精製し、新

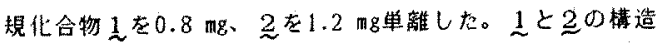
はMS, IR, 'H-NMR, i ${ }^{3} C$-NMR.及ひ2D NMRなどのスベクトル

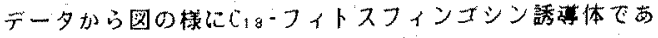
る構造と決定した。立体化学仙ついては 2,3 位間、3,4位間 のプロトンのカッブリンク定数がリ ひNUESYを测定した結果H-4'とH-2、H-4との間にNoEが観测 されたこと加ら決定した。

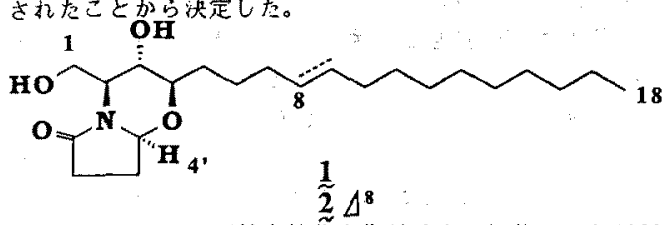

1)越野方第31回天然有機化合物討諭会要旨集 p244,1989
$3 G a 10$ 海洋性藍藻のへテロシストによる不定肧 発芽促進因子の生成

(ペんてる中研、米果京羁工大工)

○和気仁志、梅津搏紀、小林雄治、松永是 1. 目的先に演者らは、海洋性監澡抽出物中に二

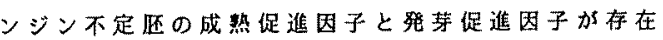
することを報告した。今回は、海洋性蓝漟のへテロ シストから発芽促進因子が生成されることを見いだ したので報告する。

2. 方法当研究空保存の海洋性監澡Anabaena sp. を用いて、へテロシスト分化を誘羊した囷体と誘算 しない娄体加ら熟水抽出物を調整した。各抽出物の 発茅促進活性は、人工種子の発芽率を比較し梚定し た。人工種子は、 $425 \mu \mathrm{m}$ 以上に成然したニンジン不 定肧をアルギン酸カルシウムで包埋したもので、明 条件下 $1 / 4$ MS 寒天培地上で14日間培烅された。

3、結果へテロシスト分化を辣桬した Anabaena sp. NKBG 060701 の抽出物 $(-N) を 100 \mu \mathrm{g} / \mathrm{ml}$ 添加し た人工租子の発芽平は $50 \%$ 、末部算囷体加 5 の抽出 物 $(+\mathrm{N})$ を $100 \mu \mathrm{g} / \mathrm{m}$ 添加した時は $30 \%$ て、無添加の

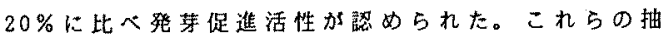
出物を透析により分画したところ共に非遝析画分に 活性が認められた。この時、罠小有㹢湠度は一Nで $10 \mu \mathrm{g} / \mathrm{ml} 、+\mathrm{N} \tau ゙ 100 \mu \mathrm{g} /$ 㙗であった。不定肧発芽促 進因子は蓝藻の細胞分化にともない生成が促進され る物筫であることが明らかになった。

3Ga12 放線菌が生産する新しい担子菌子实体垁尊

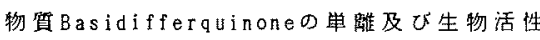

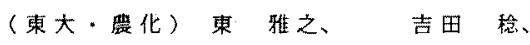
堀之内 未治、○別府輝彦

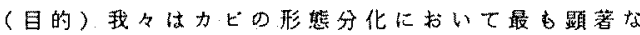
現象である担子菌の子寒体形成に興棟を持ち、微生

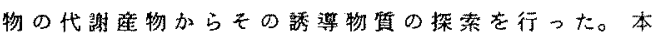
報告ではをの探索結果と、Basidifferquinoneと命名 した活性物筫の作用についてのべる。

(方法及び結果) 検定菌としてアミスギタケを用い

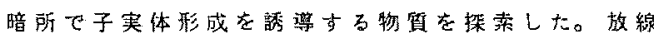
菌2700種、カビ 1900 種の培意液について䄼討した結 果、Streptonyces sp.B-412株の培弆液に活性加見 出さ机た。培盖上清加的溶媒抽出、各璉力うムク口 マトグラフィーを組み合わせ5しの培意上清から約 5 m g の活性物貿が単磪でき、精整標品法ク口ロホルム 溶液中で橙色の䊅昆を形成した。この物筫は暗所に $お い て 3 \mathrm{ng} / \mathrm{m} 1$ 亡極めて低激度で子寒体の唡の部分を

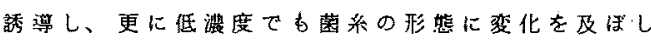
た。本物留により綉翼された柄は36-72時間の光照射 で金の形成吕誘導された。また本物質は上トヨタケ

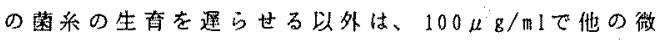
生物汇対する生育阻止蜆察されなかった。現在本

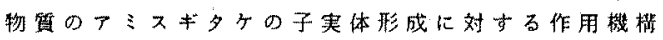
について檢討中である。 